\title{
Silica and Iron Recovery from a Residue of Iron Ore Flotation
}

\author{
P. F. F. Martins, C. A. Morais*, F. S. Lameiras, R. O. Albuquerque \\ Centro de Desenvolvimento da Tecnologia Nuclear, Belo Horizonte, Brazil \\ Email: polyfabri@yahoo.com.br, *cmorais@cdtn.br, fsl@cdtn.br, roda@cdtn.br
}

How to cite this paper: Martins, P.F.F., Morais, C.A., Lameiras, F.S. and Albuquerque, R.O. (2017) Silica and Iron Recovery from a Residue of Iron Ore Flotation. Journal of Minerals and Materials Characterization and Engineering, 5, 153-160.

https://doi.org/10.4236/jmmce.2017.54013

Received: July 4, 2015

Accepted: June 6, 2017

Published: June 9, 2017

Copyright () 2017 by authors and Scientific Research Publishing Inc. This work is licensed under the Creative Commons Attribution International License (CC BY 4.0).

http://creativecommons.org/licenses/by/4.0/

\begin{abstract}
A study of silica and iron recovery from the iron ore concentration tailing is presented. The residue is composed of $40.1 \% \mathrm{Fe}, 33.4 \% \mathrm{SiO}_{2}, 8.31 \% \mathrm{Al}_{2} \mathrm{O}_{3}$, $0.08 \% \mathrm{P}$, and $0.34 \% \mathrm{MnO}$. The developed process of silica and iron recovery consisted of size classification, magnetic separation, and removal of impurities by leaching. A concentration of $\mathrm{SiO}_{2}$ from $33.4 \%$ to $67.0 \%$, with $60.0 \%$ of mass reduction, was achieved by size classification. After magnetic separation, the $\mathrm{SiO}_{2}$ grade increased from $67.0 \%$ to $95.0 \%$, in non-magnegtic fraction and iron increased from $40.1 \%$ to $60.2 \%$ in magnetic fraction. The iron content in magnetic fraction achieved the commercial grade. In order to increase the content of silica, the impurities removal from the non-magnetic fraction was studied. The leaching agents investigated were $\mathrm{HCl}, \mathrm{H}_{2} \mathrm{SO}_{4}, \mathrm{HNO}_{3}, \mathrm{HF}$, $\mathrm{C}_{6} \mathrm{H}_{8} \mathrm{O}_{7},(\mathrm{COOH})_{2} \cdot 2 \mathrm{H}_{2} \mathrm{O}$ and $\mathrm{NaOH}$. A concentration of $98.0 \% \mathrm{SiO}_{2}$ was attained with the acid digestion.
\end{abstract}

\section{Keywords}

Industrial Residue Processing, Iron Recovery, Silica Recovery

\section{Introduction}

The largest iron reserves on Earth are composed of Banded Iron Formations (BIFs), which are altered sedimentary deposits with laminated rocks formed by alternating layers of silica and hematite-magnetite, as well as carbonates and iron silicates. One of the most important iron provinces in Brazil is the Quadrilátero Ferrífero (QF), located in the São Francisco Craton, southeastern Brazil [1].

Ferric oxides are separated from silicates by flotation or magnetic separation. The residue generated by magnetic separation consists of fine iron oxide and silicates. Two types of residues are generated by flotation. One of them is similar to sand and consists of quartz particles (greater than $85 \mathrm{wt} \%$ ) and iron oxides 
(less than $15 \mathrm{wt} \%$ ). The other one is similar to clay, consisting of quartz ultrafine particles, iron oxides and hydroxides (mainly goethite) and aluminum silicates. These residues have been used to fill mining pits or stored in dams that require permanent and costly monitoring.

A trend of reducing the iron grade and of course increasing levels of contaminants is observed in itabirites tailings in the Quadrilátero Ferrífero (Minas Gerais state, Brazil). Currently, it is known that industrially, for each ton of iron ore concentrate produced, one tailings ton is generated (about 411.8 million tonnes year) [2]. Therefore, more and more tailings will be generated, presenting challenges to its disposal in dams or reuse. Therefore, it is imperative to seek the recovery of useful minerals iron and also the contaminants contained in these tailings, aiming at the minimization of generated volumes and reduced environmental impact.

The iron ore concentration tailing in the form that it is generated may have some applications, such as a substitute for sand in cementitious products. Depending on its purity, the silica may have other applications, such as in the glass industry, ceramics, optics, electronics, etc. [3].

There are several studies related to removal of iron from silicates, aiming at purification of silica by chemical processes. Various inorganic and organic acids have been used, such as sulfuric acid $\left(\mathrm{H}_{2} \mathrm{SO}_{4}\right)$, hydrochloric acid $(\mathrm{HCl})$, oxalic acid $\left((\mathrm{COOH}) \cdot 2 \mathrm{H}_{2} \mathrm{O}\right)$ and citric acid $\left(\mathrm{C}_{6} \mathrm{H}_{8} \mathrm{O}_{7}\right)$ [4] [5]. According to Abdelkrim [6], purification of silica from flotation residue may be performed by acid leaching with percolation using a mixture of hydrofluoric acid (HF) and hydrochloric acid $(\mathrm{HCl})$ followed by an alkaline washing with sodium hydroxide $(\mathrm{NaOH})$. Santos et al. [7] evaluated the performance of leaching for purification of metallurgical grade silicon using sulfuric acid $\left(\mathrm{H}_{2} \mathrm{SO}_{4}\right)$, hydrochloric acid $(\mathrm{HCl})$, and hydrofluoric ( $\mathrm{HF}$ ) acid and nitric acid $\left(\mathrm{HNO}_{3}\right)$. Iron can also be removed by bio-hydrometallurgical processes. Iron can be leached by acid producing microorganisms, such as bacteria and fungi. Groudev [8] developed a process for iron removal at high temperatures using filtrates of cultured fungi, especially Aspergillus niger.

The sample used in this work was a reject from the Peak of Mine, provide by Vale S.A.

First the sample was chemical and physically characterized. Based on the granulochemical analysis, the fraction between the sieves of $298 \mu \mathrm{m}$ and $37 \mu \mathrm{m}$ was separated, which was subjected to wet and dry magnetic concentration to remove the magnetic fraction, iron-rich part. Leaching experiments and acid digestion were performed to reduce the levels of impurities of the non-magnetic fraction, especially aluminum and iron, in which the type and concentration of the leaching agent, the reaction time and the temperature were varied.

\section{Materials and Methods}

\subsection{Sample and Reagents}

The iron ore concentration tailing was provided by the Vale S.A. 
The experiments were performed using sulphuric acid $\left(\mathrm{H}_{2} \mathrm{SO}_{4}\right)$, hydrochloric acid $(\mathrm{HCl})$, nitric acid $\left(\mathrm{HNO}_{3}\right)$, citric acid $\left(\mathrm{C}_{6} \mathrm{H}_{8} \mathrm{O}_{7}\right)$, oxalic acid $\left((\mathrm{COOH})_{2} \cdot 2 \mathrm{H}_{2} \mathrm{O}\right)$, hydrofluoric acid (HF) and sodium hydroxide $(\mathrm{NaOH})$; all of them of analytical grade.

\subsection{Analytical Procedure}

The chemical characterization of the samples and the analytical monitoring of the experiments was done by wavelength dispersive X-ray fluorescence spectrometer-WDX (Rigaku-model ZSX Primus II), energy dispersive X-ray fluorescence spectrometer (SHIMADZU, model EDX-720), flame absorption atomic spectrometry Varian/Agilent (model AA240FS) and the determination of the minerals phases was performed by X-ray diffraction with a Rigaku spectrometer (model D/Max Ultima).

\subsection{Methodology}

Once dry, the sample was de-agglonerated, homogenized, quarted and packaged. After this preparation, the physical and chemical characterization, particle size analysis, and density measurement were performed.

Based on the granulochemical analysis, the fraction between the sieves of 298 $\mu \mathrm{m}$ and $37 \mu \mathrm{m}$ was separated, which was subjected to wet and dry magnetic concentrations to remove the magnetic fração, iron-rich part. The magnetic separations experiments were performed in a high intensity, magnetic roller separator (RER4), a medium intensity, drum magnetic separator (WDRE), and a high intensity electromagnetic separator with magnetic field of about 16,000 gauss. Part of these experiments were carried out by Inbras-Eriez.

The leaching experiments, made in batch, were carried out in a beaker with mechanical stirring in water bath and temperature control. In this step the following process variables were investigated: type and dosage of the leaching agent, agitation time, relation between leaching agent and ore, percent of solids, and temperature. The acid digestion experiments were performed in a $150 \mathrm{~mL}$ beaker on a hot plate at $200^{\circ} \mathrm{C}$ for $4 \mathrm{~h}$ and $6 \mathrm{~h}$. The digestion product was leached with water under mechanical stirring at room temperature $\left(25^{\circ} \mathrm{C}\right)$ for 1 h.

\section{Results and Discussion}

\subsection{Sample Characterization}

The chemical analysis of the sample showed $\mathrm{Fe}(40.1 \%), \mathrm{SiO}_{2}(33.4 \%), \mathrm{Al}_{2} \mathrm{O}_{3}$ (8.31\%), P (0.18\%), $\mathrm{MnO}(0.34 \%)$ and major mineral quartz $\left(\mathrm{SiO}_{2}\right)$, hematite $\left(\mathrm{Fe}_{2} \mathrm{O}_{3}\right)$, dickite $\left(\mathrm{Al}_{2} \mathrm{Si}_{2} \mathrm{O}_{5}(\mathrm{OH})_{4}\right)$, and goethite $(\mathrm{FeO} \cdot \mathrm{OH})$. The density was 3.696 $\mathrm{g} / \mathrm{cm}^{3}$.

\subsection{Mass and Metallurgical Distribution}

The mass and metallurgical distributions of the main constituents are presented in Table 1. As noted, the fraction $+37 \mu \mathrm{m}$ recovered $38.6 \%$ of the mass and 
Table 1. Mass and metallurgical distribution.

\begin{tabular}{ccccc}
\hline \multirow{2}{*}{ Size $(\mu \mathrm{m})$} & \multicolumn{4}{c}{ Distribution (\%) } \\
\cline { 2 - 5 } & Mass & $\mathrm{SiO}_{2}$ & $\mathrm{Fe}$ & $\mathrm{Al}_{2} \mathrm{O}_{3}$ \\
\hline 210 & 1.10 & 2.60 & 1.00 & 2.20 \\
149 & 6.90 & 16.2 & 2.00 & 3.60 \\
105 & 13.4 & 31.3 & 4.10 & 5.10 \\
74 & 20.7 & 44.8 & 8.60 & 6.90 \\
53 & 28.9 & 59.9 & 13.7 & 9.20 \\
44 & 34.6 & 69.5 & 17.4 & 11.6 \\
37 & 38.6 & 75.2 & 20.7 & 14.0 \\
-37 & 100.0 & 100.0 & 100.0 & 100.0 \\
\hline
\end{tabular}

Table 2. Main constituents of the samples obtained in the granulometric classification and magnetic separation.

\begin{tabular}{cccccc}
\hline \multirow{2}{*}{ Sample } & \multicolumn{7}{c}{ Grade (\%) } \\
\cline { 2 - 6 } & $\mathrm{Fe}$ & $\mathrm{SiO}_{2}$ & $\mathrm{Al}_{2} \mathrm{O}_{3}$ & $\mathrm{P}$ & $\mathrm{MnO}$ \\
\hline Original sample & 40.1 & 33.4 & 8.31 & $<0.08$ & 0.34 \\
$(-298+37) \mu \mathrm{m}$ fraction & 20.6 & 67.0 & 2.70 & $<0.08$ & 0.08 \\
Wet test, non-magnetic fraction & 0.90 & 94.5 & 3.00 & $<0.08$ & 0.01 \\
Dry test, non-magnetic fraction & 0.74 & 95.4 & 2.56 & $<0.08$ & 0.01 \\
Wet test, magnetic fraction & 60.2 & 10.9 & 1.84 & $<0.08$ & 0.17 \\
Dry test, magnetic fraction & 54.3 & 17.2 & 4.15 & $<0.08$ & 0.16 \\
\hline
\end{tabular}

$75.2 \%$ of $\mathrm{SiO}_{2}$. In the granulometric classification between $-298+37 \mu \mathrm{m}$, the silica content increased from $33.4 \%$ to $67.0 \%$.

\subsection{Magnetic Separation}

In the dry test, the silica content increased from $67.0 \%$ to $95.4 \%$ in 3 steps and in the wet test, the silica content increased from $67.0 \%$ to $94.5 \%$ in 2 steps. In the dry test, $44.8 \%$ of mass and $69.7 \%$ of silica were recovered, while in the wet test, $55.4 \%$ of mass and $84.1 \%$ of silica were recovered. The concentration of the original constituents of the sample and the fraction $-298+37 \mu \mathrm{m}$ of magnetic and non-magnetic fractions are shown in Table 2.

\subsection{Leaching}

Initially, tests were performed to choose the best leaching agent for the dissolution of $\mathrm{Fe}$ and $\mathrm{Al}$. As mentioned above, the leaching agents selected were the acids $\mathrm{HCl}, \mathrm{H}_{2} \mathrm{SO}_{4}, \mathrm{HNO}_{3}, \mathrm{HF}, \mathrm{C}_{6} \mathrm{H}_{8} \mathrm{O}_{7}$, and $(\mathrm{COOH})_{2} \cdot 2 \mathrm{H}_{2} \mathrm{O}$. The experiments were performed at $70^{\circ} \mathrm{C}, 3$ hours of reaction and $10 \%$ of solids. The results are shown in Table 3.

As shown in Table 3, under the test conditions, there was no significant difference between the leaching agents investigated in the purification of silica. 
Table 3. Effect of the leaching agent in the purification of silica from the original iron ore concentration tailing.

\begin{tabular}{ccccc}
\hline & Leaching agent & \multicolumn{2}{c}{ Dissolution (\%) } & \multirow{2}{*}{$\mathrm{SiO}_{2}$ grade (\%) } \\
\cline { 1 - 4 } $\mathrm{Acid}$ & Concentration $(\mathrm{mol} / \mathrm{L})$ & $\mathrm{Fe}$ & $\mathrm{Al}_{2} \mathrm{O}_{3}$ & \\
\hline $\mathrm{HCl}$ & 2.00 & 39.8 & 39.0 & 96.5 \\
$\mathrm{HCl}$ & 5.00 & 54.7 & 25.2 & 96.2 \\
$\mathrm{H}_{2} \mathrm{SO}_{4}$ & 5.00 & 27.8 & 15.8 & 95.2 \\
$\mathrm{H}_{2} \mathrm{SO}_{4}$ & 2.00 & 26.4 & 8.7 & 94.7 \\
$\mathrm{C}_{6} \mathrm{H}_{8} \mathrm{O}_{7}$ & 1.00 & 40.7 & 23.8 & 96.0 \\
$(\mathrm{COOH})_{2} \cdot 2 \mathrm{H}_{2} \mathrm{O}$ & 0.70 & 33.9 & 18.3 & 95.6 \\
\hline
\end{tabular}

Original sample: $0.90 \% \mathrm{Fe} ; 3.00 \% \mathrm{Al}_{2} \mathrm{O}_{3}$ and $94.5 \% \mathrm{SiO}_{2}$.

Table 4. Results and experimental conditions of alkaline leaching tests.

\begin{tabular}{cccccccc}
\hline \multirow{2}{*}{ Solid content (\%) } & $\mathrm{NaOH}(\mathrm{mol} / \mathrm{L})$ & $\mathrm{Temp} .\left({ }^{\circ} \mathrm{C}\right)$ & $\mathrm{Time}(\mathrm{h})$ & \multicolumn{2}{c}{ Dissolution $(\%)$} & $\mathrm{SiO}_{2}$ grade \\
\cline { 5 - 6 } & & & & $\mathrm{Fe}$ & $\mathrm{Al}_{2} \mathrm{O}_{3}$ & $(\%)$ \\
\hline 50 & 12.00 & 70 & 3 & 17.2 & 22.4 & 95.6 \\
70 & 12.50 & 70 & 3 & 41.0 & 41.7 & 95.7 \\
50 & 12.50 & 70 & 8 & 27.6 & 40.5 & 95.3 \\
50 & 12.50 & 25 & 24 & 34.0 & 27.5 & 95.5 \\
\hline
\end{tabular}

Original sample: $0.90 \% \mathrm{Fe} ; 3.00 \% \mathrm{Al}_{2} \mathrm{O}_{3}$ and $94.5 \% \mathrm{SiO}_{2}$.

However, $\mathrm{H}_{2} \mathrm{SO}_{4}$ was the least efficient, showing the lowest dissolution of $\mathrm{Fe}$.

To remove the $\mathrm{Al}$ in the sample, alkaline leaching tests with $\mathrm{NaOH}$ were performed. Tests were performed with $\mathrm{NaOH} 5 \mathrm{~mol} / \mathrm{L}$ and $12.5 \mathrm{~mol} / \mathrm{L}(\sim 50 \% \mathrm{w} / \mathrm{w})$, where the percentage of solids, reaction time, and temperature were varied. The experimental conditions and results of these tests are presented in Table 4.

According to the data in Table 4, the best results were obtained when using $\mathrm{NaOH}$ solution of $12.5 \%$ at $70^{\circ} \mathrm{C}$, with $\mathrm{Al}$ dissolution of $46 \%$. The results also showed that in this case a high percentage of solids $(50 \% \mathrm{w} / \mathrm{w})$ can be used.

In a following stage, alkaline leaching residues were subjected to acid leaching to increase the purity of the silica. The leaching agent used was $\mathrm{HCl}$ at the concentration of $5 \mathrm{~mol} / \mathrm{L}$. Table 5 shows the results and the conditions of these experiments.

The results in Table 5 are inconclusive. However, they show the difficulty of removal of iron and aluminum from the sample after magnetic separation.

Still in search of better conditions for reducing the level of impurities in the residue to obtain high-purity silica, another leaching test was performed with a mixture of $\mathrm{HF} 50 \%$ and $\mathrm{HCl} 25 \%$ in relation 1:1. The acid concentrations and the ratio of their mixture were chosen based on literature (Abdelkrim, 2009). The percentage of solids was $50 \%$ with a reaction time of $3 \mathrm{~h}$ at room temperature. The residue was washed with distilled water and dried at $110^{\circ} \mathrm{C}$. After that, 
Table 5. Results and experimental conditions of acid leaching.

\begin{tabular}{llllll}
\hline \multirow{2}{*}{ Solid content (\%) } & Temp. $\left({ }^{\circ} \mathrm{C}\right)$ & $\mathrm{Time}(\mathrm{h})$ & \multicolumn{2}{l}{ Dissolution $(\%)$} & $\mathrm{SiO}_{2}(\%)$ \\
\cline { 4 - 5 } & & & $\mathrm{Fe}$ & $\mathrm{Al}_{2} \mathrm{O}_{3}$ & \\
\hline 10 & 70 & 3 & 48.9 & 67.3 & 98.0 \\
20 & 70 & 5 & 24.1 & 66.9 & 97.1 \\
50 & 70 & 5 & 21.4 & 14.9 & 96.0 \\
20 & 70 & 5 & 39.7 & 20.6 & 97.2 \\
50 & 70 & 5 & 27.7 & 10.2 & 96.1 \\
50 & 70 & 7 & 19.3 & 29.7 & 97.4 \\
50 & 25 & 24 & 30.2 & 71.9 & 96.4 \\
\hline
\end{tabular}

Table 6. Results of leaching tests with the $\mathrm{HF} / \mathrm{HCl}$ mixture and with $\mathrm{NaOH}$.

\begin{tabular}{ccccccc}
\hline \multirow{2}{*}{ Leaching agent } & Concentration (\%) & \multicolumn{4}{c}{ Concentration in residue (\%) } & \multicolumn{3}{c}{ Dissolution (\%) } & \multirow{2}{*}{$\mathrm{SiO}_{2}$ (\%) } \\
\cline { 3 - 6 } & & $\mathrm{Fe}$ & $\mathrm{Al}_{2} \mathrm{O}_{3}$ & $\mathrm{Fe}$ & $\mathrm{Al}_{2} \mathrm{O}_{3}$ & \\
\hline $\mathrm{HF} / \mathrm{HCl}$ & $50 / 25$ & 0.38 & 0.70 & 37.2 & 74.4 & 97.4 \\
$\mathrm{NaOH}$ & 10 & 0.28 & 0.66 & 18.7 & 6.91 & 97.8 \\
\hline
\end{tabular}

Original sample: $0.74 \% \mathrm{Fe} ; 2.56 \% \mathrm{Al}_{2} \mathrm{O}_{3}$ and $95.4 \% \mathrm{SiO}_{2}$.

Tabel 7. $\mathrm{Fe}, \mathrm{Al}_{2} \mathrm{O}_{3}$ e $\mathrm{SiO}_{2}$ grade in residue from acid and alkaline digestion of the nonmagnetic fraction.

\begin{tabular}{|c|c|c|c|c|c|c|c|}
\hline \multirow{2}{*}{$\mathrm{RAM}(\mathrm{kg} / \mathrm{t})$} & \multicolumn{2}{|c|}{ Dissolution (\%) } & \multirow{2}{*}{$\mathrm{SiO}_{2}(\%)$} & \multicolumn{4}{|c|}{ Impurity grade (\%) } \\
\hline & $\mathrm{Fe}$ & $\mathrm{Al}_{2} \mathrm{O}_{3}$ & & $\mathrm{Fe}$ & $\mathrm{Al}_{2} \mathrm{O}_{3}$ & $\mathrm{P}$ & $\mathrm{SO}_{3}$ \\
\hline 500 & 72.4 & 73.9 & 97.7 & 0.30 & 0.70 & 0.16 & 0.91 \\
\hline 1000 & 73.6 & 75.9 & 98.0 & 0.29 & 0.66 & 0.09 & 0.93 \\
\hline 1500 & 72.2 & 78.4 & 98.2 & 0.31 & 0.60 & 0.04 & 0.78 \\
\hline
\end{tabular}

Original sample: $0.74 \% \mathrm{Fe} ; 2.56 \% \mathrm{Al}_{2} \mathrm{O}_{3}$ and $95.4 \% \mathrm{SiO}_{2}$. $\mathrm{RAM}=$ acid/ore relation.

a very alkaline leaching with $\mathrm{NaOH} 12.50 \mathrm{~mol} / \mathrm{L}$ was performed, aiming at the dissolution of the remaining Al. The results of these tests are presented in Table 6.

As shown in Table 6, for the conditions under which the tests were performed, there was no gain in purification of silica compared with previous experiments. Another expected drawback with the mixture $\mathrm{HF} / \mathrm{HCl}$ is a high dissolution of silica $(7.0 \% \mathrm{w} / \mathrm{v})$. In leaching experiments, the silica content raises from $94.0 \%$ to $98.0 \%$. Thus, the acid digestion with concentrated $\mathrm{H}_{2} \mathrm{SO}_{4}$ at high temperature was investigated, as shown in the next section.

\subsection{Digestion}

Acid digestion tests were performed at $200^{\circ} \mathrm{C}$, using concentrated $\mathrm{H}_{2} \mathrm{SO}_{4}$ with three different sample/acid relations, 500, 1000 and $1500 \mathrm{~kg} / \mathrm{t}$, and 4 hours of reaction. The conditions and results of these experiments are presented in Table 7. After completion of the reaction time, distilled $\mathrm{H}_{2} \mathrm{O}$ was added at a ratio of 
$10 \%$ of solids and stirred for one hour before proceeding to filtering the pulp.

According to the results in Table 7, in acid digestion tests, higher $\mathrm{Fe}$ and $\mathrm{Al}$ dissolution was obtained. The silica content was maintained at $98.0 \%$.

\section{Conclusions}

The steps that contributed the most to the purification of the silica from the flotation residue were granulometric classification and magnetic separation. The granulochemical analysis of the flotation residue showed that $79.0 \%$ of iron and $86.0 \%$ of aluminum are contained in the fraction below $37 \mu \mathrm{m}$. In desliming of the sample in $37 \mu \mathrm{m}$, recovery was $75.2 \%$ silica and $61.4 \%$ mass reduction. In this step, the $\mathrm{SiO}_{2}$ content increased from $33.4 \%$ to $67.0 \%$. In magnetic concentration, the wet experiment was more efficient than the dry one. The cleaning concentration was performed in 3 stages, and the wet one, in 2 stages. However, the final composition of the non-magnetic and magnetic fractions was similar for the two techniques $\left(\sim 95.0 \% \mathrm{SiO}_{2}\right), 55.0 \%$ of the mass and $84.1 \%$ of $\mathrm{SiO}_{2}$ were recovered in the wet concentration, while in the dry concentration, the mass recovered was $44.8 \%$, including $69.7 \%$ of $\mathrm{SiO}_{2}$.

The purification experiments of silica by chemical processes indicated the difficulty of removing the contaminants, $\mathrm{Fe}$ and $\mathrm{Al}$, present in the sample after the magnetic classification. Quite drastic conditions were used even in acid and alkaline leaching as well as in acid digestion, the maximum silica obtained was $98.0 \%$.

\section{Acknowledgements}

The authors would like to acknowledge "Vale S.A." for supplying the sample and the Inbras-Eriez Lc for conducting magnetic separation experiments. The authors are grateful to the Government agencies FAPEMIG, FINEP, CNPq and CAPES for the financial support. Sincere thanks to CDTN's technicians who were involved in this work.

\section{References}

[1] Rosière, C.A., Spier, C.A., Rios, F.J. and Suckau, V.E. (2008) The Itabirite from the Quadrilátero Ferrífero and Related High-Grade Ores: An Overview. Reviews in Economic Geology, 15, 223-254.

[2] DNPM. Mineral Summary (2015). http://www.dnpm.gov.br/dnpm/sumarios/sumario-mineral-2015

[3] Ciftja, A., Engh, T.A. and Tangstad, M. (2008) Refining and Recycling of Silicon: A Review.

[4] Veglió, F., et al. (1998) Drum Leaching Tests in Iron Removal from Quartz Using Oxalic and Sulphuric Acids. International Journal of Mineral Processing, 54, 183 200.

[5] Williams, P. (2008) Chemical Leaching of Iron Ore Using a Range of Acids and Oxidative Chemicals.

[6] Abdelkrim, K. (2009) Acid Leaching Technology for Obtaining a High-Purity of Silica for Photovoltaic Area. Chemical Enginnering Transactions, 17, 197-202. 
[7] Santos, I.C., et al. (1990) Purification of Metallurgical Grade Silicon by Acid Leaching. Hydrometallurgy, 23, 237-246.

[8] Groudev, S.N. (1987) Use of Heterotrophic Microorganisms in Mineral Biotechnology. Engineering in Life Sciences, 7, 299-306.

https://doi.org/10.1002/abio.370070404

\section{Scientific Research Publishing}

Submit or recommend next manuscript to SCIRP and we will provide best service for you:

Accepting pre-submission inquiries through Email, Facebook, LinkedIn, Twitter, etc. A wide selection of journals (inclusive of 9 subjects, more than 200 journals)

Providing 24-hour high-quality service

User-friendly online submission system

Fair and swift peer-review system

Efficient typesetting and proofreading procedure

Display of the result of downloads and visits, as well as the number of cited articles Maximum dissemination of your research work

Submit your manuscript at: http://papersubmission.scirp.org/

Or contact jmmce@scirp.org 